\title{
Hyperglycosylated hCG drives malignancy in cancer cases.
}

\author{
Laurence A. Cole* \\ USA hCG Reference Service, 34 Broadmoor Way, P.O. Box 950 Angel Fire, New Mexico
}

\begin{abstract}
Purpose: Trophoblastic cancers (Choriocarcinoma, testicular and ovarian germ cell malignancies) secrete hyperglycosylated hCG and non-trophoblastic cancers secrete hyperglycosylated hCG free $\beta$ subunit.Both are structural variants of hCG independent to the hormone hCG. They are autocrines acting on a transforming growth factor $\beta$-II (TGF- $\beta$-II), receptor not acting on the hormone receptor. Here these molecules were examined as drivers of malignancy.

Methods: The cancer cell lines were examined, how they enzymatically invaded Matrigel chambers and how their growth responded to hyperglycosylated hCG and hyperglycosylated hCG free $\beta$-subunit signals. Use of hyperglycosylated hCG and hyperglycosylated hCG free $\beta$-subunit as tumor markers is examined in 959 cancer serum samples and 2257 cancer urine samples, plus 284 urines from benign disease patients. In addition, $56 \mathrm{new}$ ovarian cancer urines were collected and tested in the supersensitive B204 assay.

Results: Hyperglycosylated hCG and its free $\beta$-subunit are both strong promoters of malignancy functions. A total of $100 \%$ of trophoblastic malignancies produced hyperglycosylated hCG markers in serum and urine. A total of $30 \%$ of non-trophoblastic cancers were detected in serum and $44 \%$ in urine. As shown, in reality, considering simple and complex autocrine secretion, $100 \%$ of nontrophoblastic malignancies produce hyperglycosylated hCG and hyperglycosylated hCG free $\beta$ subunit markers in urine. As demonstrated, hyperglycosylated hCG and its free $\beta$-subunit exist in all human cancers and promote malignancy. Multiple other researchers have confirmed these results.

Discussion: It is inferred that hyperglycosylated hCG and its free $\beta$-subunit are produced by all or most human cancers, and are the promoters of malignancy.
\end{abstract}

Keywords: Hyperglycosylated hCG, Steroidogenesis, Ovulation, Luteogenesis.

Accepted on 03 August, 2017

\section{Introduction}

What promotes malignancy in human cancers? A many times asked and never answered issue. Many authors have suggested oncogenic proteins, such as transforming growth factor $\beta$ (TGF- $\beta$ ), TGF- $\beta$ agonists and TGF- $\beta$ antagonists.

The question still remains an issue and still remains unanswered [1-13]. This issue is addressed here, cancer hyperglycosylated $\mathrm{hCG}$ and hyperglycosylated hCG free $\beta$ subunit, both TGF- $\beta$ antagonists, are seemingly the human malignancy promoter that differentiate benign and malignant cells.

As proposed in this article, cancer hyperglycosylated hCG is the most promising human cancer malignancy promoter. Hyperglycosylated hCG was discovered by me in 1997 [14]. It is a second form of hCG, a TGF- $\beta$ antagonist, yet a completely independent and separate molecule to the hormone hCG.

It shares an identical $\alpha$-subunit and $\beta$-subunit amino acid sequence with hCG, and only differs from hCG by having three or four type $2 \mathrm{O}$-linked oligosaccharides on the hCG $\beta$-subunit C-terminal peptide, hexasexaccharides and pentasaccharide verses three of four sugar type 1, trisaccharide and tetrasaccharadide structures found on the hormone hCG (Figure 1).
The three dimensional structure of pregnancy and cancer hyperglycosylated $\mathrm{hCG}$ is virtually identical to the hormone hCG (Butler SA, Computer+X-ray 3D Models (Figure 1) [15]. Hyperglycosylated hCG is an autocrine binding a TGF- $\beta$-II receptor [16-18], and not acting at all on an hCG/luteinizing hormone (LH) receptor like the hormone hCG (Figure 1).

Hyperglycosylated hCG is made by invasive cytotrophoblast cells during pregnancy, while the hormone hCG is made by fused syncytiotrophoblast cells during pregnancy $[19,20]$. Hyperglycosylated hCG acts on the autocrine cytotrophoblast cell TGF- $\beta$-II receptor driving implantation of the blastocyst in the beginning of pregnancy [20,21], and deep implantation of hemochorial placentation at 10 weeks gestation [22,23], and during the menstrual cycle finalizes ovulation [24]. In all three processes, the autocrine TGF- $\beta$-II receptor drives invasive metalloproteinase and collagenase production [12,19], cell growth [19,25] and blocks cell apoptosis [26-28], three malignancy-like steps. 


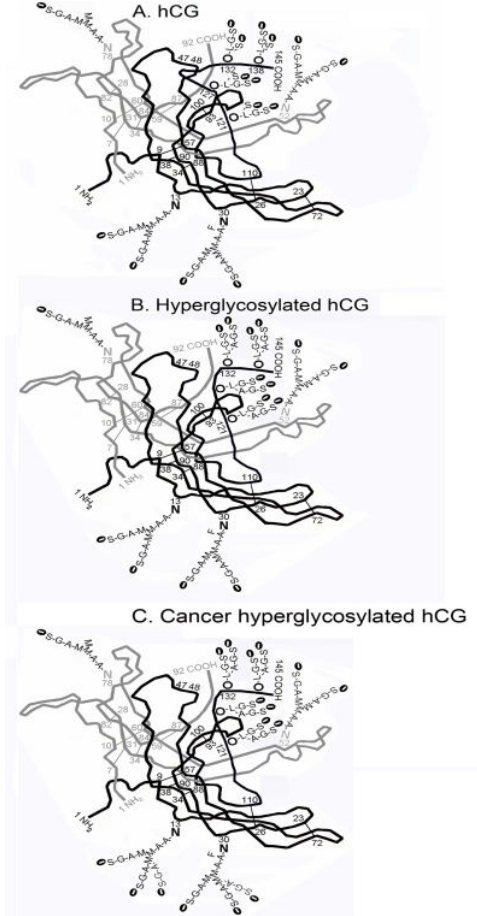

Figure 1. The three dimensional structure of the hormone $h C G(A)$, and the autocrines hyperglycosylated $h C G(B)$, and cancer hyperglycosylated $h C G(C)$. Butler computer and crystallography model 2016.

The hyperglycosylated Hcg -TGF- $\beta$-II pathway is the solitary enzymatic invasion pathway and cellular growth pathway coded in the human genome. Cancer cells steal this hyperglycosylated $\mathrm{hCG}$ and use it to drive human malignancy, to drive enzymatic invasion, growth and blockage of apoptosis in cancer cells [26-28].

This is cancer hyperglycosylated hCG produced by trophoblastic cancers, and hyperglycosylated hCG free $\beta$ subunit produced by non-trophoblastic cancers [29], the molecules that drives implantation in pregnancy, seemingly drives human malignancy.

Under medical dictionary definition, malignancy is the "process of cancer advancement, cancer growth, and cancer tissue invasion." In the Merriam-Webster dictionary malignancy, it is defined as "aggressively malicious, tending to produce death or deterioration, tending to infiltrate, metastasize, and terminate fatally."

As interpreted in this article, malignancy means the process of cancer advancement, cancer growth promotion, and cancer tissue invasion. We test hyperglycosylated hCG and its free $\beta$ subunit for these malignancy properties, and how a malignancy promoter absolutely differentiates cancers and benign diseases.

The ability of trophoblastic cancers to produce hyperglycosylated hCG was confirmed and non-trophoblastic cancers produce hyperglycosylated hCG free $\beta$-subunit. Then show that both the molecules produced by cancers have malignancy properties. Finally, the occurrence of these tumor agents was examined to show that $100 \%$ of cancers produce these malignancy agents.

\section{Materials and Methods}

Serum samples, 959, and urine samples 2257 were collected from men and women attending the oncology, thoracic oncology and gynecologic oncology clinics at Yale NewHaven Hospital in New Haven CT. Samples collection was started in 1992, multiple tubes of serum and urine were libraried in $-80 \mathrm{C}$ Revco freezers with the certification of Yale Clinical Research Internal Review Board seeking full patient approval. Additionally, 283 urine samples from women and men with benign disease were collected at Yale New Haven Hospital Oncology clinics and 154 serum and urine samples were at Oncology clinic from healthy and treated individuals.

A further group of 56 subjects with ovarian cancer supplied urines in 1999 for super sensitive B204 test examination with full IRB approval. At Yale University verbal consent was considered sufficient for collecting urine samples for tumor marker studies, signed consent was needed for serum samples.

Cell lines, JEG-3 choriocarcinoma cell line, JAr choriocarcinoma cell line, NTERA testicular germ cell cancer, T24 epithelial bladder carcinoma cell line, KLE endometrial adenocarcinoma cell line, CaSki epidermoid cervical cancer cells, ScaBER squamous bladder cancer cell, Hec-1-a endometrial cancer cells, SK-MES-1 lung epithelial cancer cells and KM-H2 Hodgkin's lymphoma cancer cells were all maintained continuously in culture in T75 flasks using high glucose Dulbecco's modified Eagle's medium with $10 \%$ fetal bovine serum. Cells were sub-cultured using $1 \mathrm{X}$ trypsin.

In the experiment the cells were cultured in flasks 3-5 days in quadruplicate until they reach approximately $70 \%$ flask confidence. Then medium was changed and replaced with medium containing $0 \mathrm{ng} / \mathrm{ml}, 20 \mathrm{ng} / \mathrm{ml}$ and $200 \mathrm{ng} / \mathrm{ml}$ hyperglycosylated hCG (JAr, JEG-3 and NTERA cell lines), or $0 \mathrm{ng} / \mathrm{ml}, 20 \mathrm{ng} / \mathrm{ml}$ and $200 \mathrm{ng} / \mathrm{ml}$ hyperglycosylated hCG free $\beta$-subunit (T24, KLE, CaSki, ScaBER, Hec-1-a, SK-MES-1 and KM-H2 cell lines). Cells were cultured for $24 \mathrm{~h}$ and the cell number determined in each flask using a hemocytometer.

Matrigel basement membrane chambers were purchased from Corning Inc. (Corning, NY). Matrigel chambers were managed according to manufacturer's instructions, and manufacturer suggested calculation of proportion penetration. Cells, $70 \%$ confluent flasks of cells were suspended and transferred to Matrigel chambers, and cultured in Matrigel chambers for $24 \mathrm{~h}$ and proportion penetration or invasion determined.

Zero time culture cells were plated onto Matrigel membranes and control inserts (Biocoat Matrigel invasion membranes, BD Biosciences, Bedford, MA 01730), and cultured at $37^{\circ} \mathrm{C}$ for 24 $\mathrm{h}$ in Dulbecco's modified Eagle's medium with $10 \%$ fetal bovine serum in quadruplicate. Matrigel membranes were processed and percentage invasion calculated. Briefly, membranes were rehydrated in the incubator for $2 \mathrm{~h}$ before use. Membranes and control inserts were then plated $(25,000$ cells in 0.5 medium per plate).

Table 1. What is produced by cancer cells? 


\begin{tabular}{|c|c|}
\hline Cells & $\begin{array}{l}\text { Effect (mean } \\
\text { deviation) }\end{array}$ \\
\hline \multicolumn{2}{|l|}{ JEG-3 choriocarcinoma cells } \\
\hline Control cultures & $\begin{array}{l}48 \pm 11 \% \text { invasion of basement } \\
\text { membrane }\end{array}$ \\
\hline \multirow[t]{2}{*}{ Control+100 ng/ml hyperglycosylated hCG } & $\begin{array}{l}88 \pm 6.0 \% \text { invasion of basement } \\
\text { membrane }\end{array}$ \\
\hline & Ttest $P=0.010$ \\
\hline \multicolumn{2}{|l|}{ NTERA testicular germ cells } \\
\hline Control culture & $\begin{array}{l}36 \pm 12 \% \text { invasion of basement } \\
\text { membrane }\end{array}$ \\
\hline \multirow[t]{2}{*}{ Control+100 ng/ml hyperglycosylated hCG } & $\begin{array}{l}78 \pm 8.1 \% \text { invasion of basement } \\
\text { membrane }\end{array}$ \\
\hline & Ttest $P=0.022$ \\
\hline \multicolumn{2}{|l|}{ CaSki epidermoid cervical cancer cells } \\
\hline Control culture & $\begin{array}{l}49 \pm 15 \% \text { invasion of basement } \\
\text { membrane }\end{array}$ \\
\hline \multirow[t]{2}{*}{$\begin{array}{l}\text { Control+100 ng/ml hyperglycosylated hCG } \\
\beta \text {-subunit }\end{array}$} & $\begin{array}{l}69 \pm 6.5 \% \text { invasion of basement } \\
\text { membrane }\end{array}$ \\
\hline & Ttest $P=0.020$ \\
\hline \multicolumn{2}{|l|}{ SK-MES-1 Epithelial lung cancer } \\
\hline Control culture & $\begin{array}{l}48 \pm 11 \% \text { invasion of basement } \\
\text { membrane }\end{array}$ \\
\hline \multirow[t]{2}{*}{$\begin{array}{l}\text { Control+100 ng/ml hyperglycosylated hCG } \\
\beta \text {-subunit }\end{array}$} & $\begin{array}{l}76 \pm 6.9 \% \text { invasion of basement } \\
\text { membrane }\end{array}$ \\
\hline & Ttest $\mathrm{P}=0.0055$ \\
\hline
\end{tabular}

Plates were cultured for $24 \mathrm{~h}$, and membranes removed from inserts using a scalpel. Membranes were transferred to a slide using Cytoseal mounting medium (Stephens Scientific Inc., Riverdale NJ), exposing the under surface and invaded cells. Cells were stained with DIF-Quick Stain (IMEB Inc., Chicago IL) to mark nuclei. Invaded cells were counted at 9 marked positions and were averaged for each insert. Cell penetration or invasion of membranes is directly compared to that of correspondingly cultured control inserts and percentage invasion calculated using the formula provided by the manufacturer.

All samples were tested by immunometric 96 well microtiter plate assays using Immulon-1 flat bottomed plates. For B152 hyperglycosylated hCG and hyperglycosylated hCG free $\beta$ subunit plates were coated with $1 / 1000 \mathrm{~B} 152$, or $15 \mu \mathrm{l}$ antibody in $22 \mathrm{ml}$ coating buffer. For B204 urine hyperglycosylated hCG free $\beta$-subunit plus $\beta$-core fragment plates were coated with B204 $4 \mathrm{mg} / \mathrm{ml}$ in $22 \mathrm{ml}$ coating buffer. For the super sensitive B204 assay plates were coated at 0.40 $\mathrm{mg} / \mathrm{ml}$ in $22 \mathrm{ml}$ coating buffer. For the FBT11 free $\beta$-subunit assay plates were coated with $0.033 \mathrm{ml}$ FBT11 antibody concentrate in $22 \mathrm{ml}$ coating buffer.

The secondary antibody used was 4001-POD for all assays, a monoclonal antibody specific to core hCG $\beta$-subunit. Coated plates were incubated with $0.2 \mathrm{ml}$ sample or standard and incubated $2 \mathrm{~h}$ at room temperature with shaking for the B204 and FBT11 assay, $6 \mathrm{~h}$ at room temperature for the super sensitive B204 assay, and $4 \mathrm{~h}$ at room temperature for the B152 assay. In all 3 cases, the coating with the peroxidase labeled secondary antibody, 4001 POD was $2 \mathrm{~h}$ at room temperature. Finally, $200 \mu \mathrm{l}$ of substrate (TMB reagent, dilute $50 \%$ with water [Sigma part\#T8665]) is added to each well. After approximately $15 \mathrm{~min}$ incubation reaction is topped by the addition of $50 \mu \mathrm{l}$ of $2 \mathrm{~N} \mathrm{HCl}$. Absorbance is then read on the titerplate reader at $450 \mathrm{~nm}$.

The B152 hyperglycosylated hCG and hyperglycosylated hCG free $\beta$-subunit assay is tested with $5 \mathrm{C} 5$ hyperglycosylated $\mathrm{hCG}$ standards at $2.0 \mathrm{fmol} / \mathrm{ml}, 8.0 \mathrm{fmol} / \mathrm{ml}, 32 \mathrm{fmol} / \mathrm{ml}, 128 \mathrm{fmol} / \mathrm{ml}$ and $512 \mathrm{fmol} / \mathrm{ml}$. The B204 assay is tested with FEDE $\beta$-core fragment standard at $2.0 \mathrm{fmol} / \mathrm{ml}, 8.0 \mathrm{fmol} / \mathrm{ml}, 32 \mathrm{fmol} / \mathrm{ml}, 128$ $\mathrm{fmol} / \mathrm{ml}$ and $512 \mathrm{fmol} / \mathrm{ml}$. The super sensitive B204 assay uses standards at $0.1 \mathrm{fmol} / \mathrm{ml}, 0.4 \mathrm{fmol} / \mathrm{ml}, 1.6 \mathrm{fmol} / \mathrm{ml}, 6.4 \mathrm{fmol} / \mathrm{ml}$ and $25.6 \mathrm{fmol} / \mathrm{ml}$. The FBT11 assay is calibrated with recombinant hCG $\beta$-subunit standards at $4 \mathrm{ng} / \mathrm{ml}, 1 \mathrm{ng} / \mathrm{ml}, 0.24$ $\mathrm{ng} / \mathrm{ml}, 0.1 \mathrm{ng} / \mathrm{ml}$ and $0.04 \mathrm{ng} / \mathrm{ml}$.

Specificity studies show that the B152 assay detect hyperglycosylated hCG, hyperglycosylated hCG $\beta$-subunit, nicked hyperglycosylated hCG and nicked hyperglycosylated hCG $\beta$-subunit. With $<0.2 \%$ detection of the hormone hCG, and its dissociated hCG $\beta$-subunit. The B204 assay detects $\beta$-core fragment, hCG free $\beta$-subunit, nicked hCG free $\beta$-subunit, hyperglycosylated hCG $\beta$-subunit and nicked hyperglycosylated hCG $\beta$-subunit. The FBT11 assay detects hCG free $\beta$-subunit, nicked hCG free $\beta$-subunit, hyperglycosylated hCG $\beta$-subunit and nicked hyperglycosylated hCG $\beta$-subunit [19].

Serum samples were also detected for total hCG (hCG, + nicked $\mathrm{hCG}$, +nicked $\mathrm{hCG}$ missing $\beta$-subunit $\mathrm{C}$-terminal peptide, + hCG free $\beta$-subunit, + nicked $\beta$-subunit, + nicked $\beta$ subunit missing $\beta$-subunit $\mathrm{C}$-terminal peptide, +hyperglycosylated hCG, +nicked hyperglycosylated hCG, +nicked hyperglycosylated hCG free $\beta$-subunit) using the automated Siemens Immulite assay. Tests were run according to manufacturer's instruction using a total hCG standard mass curve, recombinant hCG $(4 \mathrm{ng} / \mathrm{ml}, 1 \mathrm{ng} / \mathrm{ml}, 0.25 \mathrm{ng} / \mathrm{ml}, 0.5$ $\mathrm{ng} / \mathrm{ml}, 0.2 \mathrm{ng} / \mathrm{ml}$ and $0.09 \mathrm{ng} / \mathrm{ml}$ ), run with every group of samples. All tumor marker data was entered into Microsoft Excel spreadsheets and analyzed and sorted by diagnosis code.

\section{Results and Discussion}

\section{What do cancer cells secrete?}

The freezers were searched for stored cancer patient serum and used for tumor marker studies and found 32 trophoblastic cancer (choriocarcinoma, ovarian germ cell and testicular germ cell cancers) serum samples and 92 non-trophoblastic cancer serum samples. All were tested for total hCG in the Siemens Immulite assay, for hyperglycosylated hCG and hyperglycosylated hCG $\beta$-subunit in the B152 assay, and for 
Citation: Cole LA. Hyperglycosylated hCG drives malignancy in cancer cases. J Mol Oncol Res. 2017;1(1):1-21.

free $\beta$-subunit verses $\alpha$ - $\beta$ - dimer using the FBT11 assay (Table $1)$.

Table 2: Promotion of cancer cell invasion in quadruplicate $70 \%$ confluent Matrigel basement membrane invasion chambers by $C 5$ hyperglycosylated $h C G$ and its $\beta$-subunit.

\begin{tabular}{|c|c|c|c|c|c|}
\hline \multicolumn{2}{|l|}{ Case or sample } & $\begin{array}{l}\text { Immulite } \\
1000 \text { assay }\end{array}$ & $\begin{array}{l}\text { B152 } \\
\text { assay }\end{array}$ & $\begin{array}{l}\text { B152 } \\
\text { assay }\end{array}$ & $\begin{array}{l}\text { FBT11 } \\
\text { assay }\end{array}$ \\
\hline \multicolumn{6}{|l|}{ Standards } \\
\hline \multicolumn{2}{|c|}{$\begin{array}{l}\text { Recombinant hCG (Ovidrel), } \\
1000 \mathrm{ng} / \mathrm{ml}\end{array}$} & 1007 & 0.13 & $0.01 \%$ & 1.17 \\
\hline \multicolumn{2}{|c|}{$\begin{array}{l}\text { Recombinant hCG } \beta \text {-subunit, } \\
600 \mathrm{ng} / \mathrm{ml}\end{array}$} & 602 & 0.11 & $0.01 \%$ & 615 \\
\hline \multicolumn{2}{|c|}{$\begin{array}{l}\text { Hyperglycosylated } \\
\text { standard C5, } 1000 \mathrm{ng} / \mathrm{ml}\end{array}$} & 997 & 995 & $\begin{array}{l}100.00 \\
\%\end{array}$ & 14 \\
\hline \multicolumn{2}{|c|}{$\begin{array}{l}\text { C5 free } \beta \text {-subunit standard, } \\
600 \mathrm{ng} / \mathrm{ml}\end{array}$} & 578 & 687 & $\begin{array}{l}100.00 \\
\%\end{array}$ & 610 \\
\hline \multicolumn{6}{|c|}{ Trophoblastic cancers } \\
\hline \multicolumn{2}{|c|}{$\begin{array}{l}\text { Choriocarcinoma case } 3 \text {, pre- } \\
\text { therapy }\end{array}$} & 21200 & 23300 & $110.00 \%$ & 1172 \\
\hline \multicolumn{2}{|c|}{$\begin{array}{l}\text { Choriocarcinoma case } 7 \text {, pre- } \\
\text { therapy }\end{array}$} & 33700 & 34700 & $\begin{array}{l}103.00 \\
\%\end{array}$ & 1610 \\
\hline \multicolumn{2}{|c|}{$\begin{array}{l}\text { Choriocarcinoma case } 8 \text {, pre- } \\
\text { therapy }\end{array}$} & 57400 & 54600 & $95.00 \%$ & 5680 \\
\hline \multicolumn{2}{|c|}{$\begin{array}{l}\text { Choriocarcinoma case } 11 \text {, pre- } \\
\text { therapy }\end{array}$} & 20600 & 19900 & $97.00 \%$ & 2010 \\
\hline \multicolumn{2}{|c|}{$\begin{array}{l}\text { Choriocarcinoma case } 12 \text {, pre- } \\
\text { therapy }\end{array}$} & 27500 & 30100 & $\begin{array}{l}109.00 \\
\%\end{array}$ & 5330 \\
\hline \multicolumn{2}{|c|}{$\begin{array}{l}\text { Choriocarcinoma case } 23 \text {, pre- } \\
\text { therapy }\end{array}$} & 153400 & 155000 & $\begin{array}{l}101.00 \\
\%\end{array}$ & 15740 \\
\hline \multicolumn{2}{|c|}{$\begin{array}{l}\text { Choriocarcinoma case } 25 \text {, pre- } \\
\text { therapy }\end{array}$} & 34700 & 36800 & $\begin{array}{l}106.00 \\
\%\end{array}$ & 1230 \\
\hline \multicolumn{2}{|c|}{$\begin{array}{l}\text { Choriocarcinoma case } 26 \text {, pre- } \\
\text { therapy }\end{array}$} & 43400 & 47700 & $110.00 \%$ & 1250 \\
\hline \multicolumn{2}{|c|}{$\begin{array}{l}\text { Choriocarcinoma case } 32 \text {, pre- } \\
\text { therapy }\end{array}$} & 210500 & 210200 & $\begin{array}{l}100.00 \\
\%\end{array}$ & 15750 \\
\hline \multicolumn{2}{|l|}{$\begin{array}{l}\text { Choriocarcinoma } \\
\text { during therapy }\end{array}$} & 2500 & 2100 & $84.00 \%$ & 155 \\
\hline $\begin{array}{l}\text { Choriocarcinoma } \\
\text { during therapy }\end{array}$ & case 41 & 3700 & 2900 & $78.00 \%$ & 505 \\
\hline $\begin{array}{l}\text { Choriocarcinoma } \\
\text { during therapy }\end{array}$ & case 42 , & 1600 & 870 & $54.00 \%$ & 360 \\
\hline $\begin{array}{l}\text { Choriocarcinoma } \\
\text { during therapy }\end{array}$ & case 47 & 9900 & 9900 & $\begin{array}{l}100.00 \\
\%\end{array}$ & 1260 \\
\hline $\begin{array}{l}\text { Choriocarcinoma } \\
\text { during therapy }\end{array}$ & case 48 & 20400 & 19000 & $93.00 \%$ & 1880 \\
\hline $\begin{array}{l}\text { Choriocarcinoma } \\
\text { during therapy }\end{array}$ & case 49 & 1600 & 1010 & $63.00 \%$ & 29 \\
\hline $\begin{array}{l}\text { Choriocarcinoma } \\
\text { during therapy }\end{array}$ & case 50 & 1100 & 1010 & $91.00 \%$ & 106 \\
\hline $\begin{array}{l}\text { Choriocarcinoma } \\
\text { during therapy }\end{array}$ & case 54 & 3300 & 2500 & $76.00 \%$ & 230 \\
\hline $\begin{array}{l}\text { Choriocarcinoma } \\
\text { during therapy }\end{array}$ & case 57 & 3600 & 3100 & $86.00 \%$ & 410 \\
\hline
\end{tabular}

\begin{tabular}{|c|c|c|c|c|}
\hline $\begin{array}{l}\text { Choriocarcinoma case } 69 \text {, } \\
\text { during therapy }\end{array}$ & 1050 & 1050 & $\begin{array}{l}100.00 \\
\%\end{array}$ & 89 \\
\hline $\begin{array}{l}\text { Choriocarcinoma case } 61 \text {, } \\
\text { during therapy }\end{array}$ & 6300 & 5900 & $94.00 \%$ & 311 \\
\hline $\begin{array}{l}\text { Ovarian germ cell cancer case } \\
1, \text { pre-therapy }\end{array}$ & 13400 & 14000 & $\begin{array}{l}104.00 \\
\%\end{array}$ & 2230 \\
\hline $\begin{array}{l}\text { Ovarian germ cell cancer case } \\
4 \text {, pre-therapy }\end{array}$ & 8800 & 8800 & $\begin{array}{l}100.00 \\
\%\end{array}$ & 547 \\
\hline $\begin{array}{l}\text { Ovarian germ cell cancer case } \\
5, \text { pre-therapy }\end{array}$ & 17600 & 17100 & $97.00 \%$ & 3120 \\
\hline $\begin{array}{l}\text { Ovarian germ cell cancer case } \\
6, \text { pre-therapy }\end{array}$ & 33400 & 34300 & $\begin{array}{l}102.00 \\
\%\end{array}$ & 11560 \\
\hline $\begin{array}{l}\text { Ovarian germ cell cancer case } \\
7 \text {, pre-therapy }\end{array}$ & 18900 & 18700 & $99.00 \%$ & 196 \\
\hline $\begin{array}{l}\text { Ovarian germ cell cancer case } \\
11, \text { pre-therapy }\end{array}$ & 16200 & 16100 & $99.00 \%$ & 151 \\
\hline $\begin{array}{l}\text { Testicular germ cell cancer } \\
\text { case } 7 \text {, pre-therapy }\end{array}$ & 10400 & 10600 & $\begin{array}{l}102.00 \\
\%\end{array}$ & 655 \\
\hline $\begin{array}{l}\text { Testicular germ cell cancer } \\
\text { case } 9 \text {, pre-therapy }\end{array}$ & 14500 & 14700 & $99.00 \%$ & 907 \\
\hline $\begin{array}{l}\text { Testicular germ cell cancer } \\
\text { case } 10, \text { pre-therapy }\end{array}$ & 19100 & 19300 & $\begin{array}{l}101.00 \\
\%\end{array}$ & 430 \\
\hline $\begin{array}{l}\text { Testicular germ cell cancer } \\
\text { case 11, pre-therapy }\end{array}$ & 11000 & 11100 & $\begin{array}{l}101.00 \\
\%\end{array}$ & 1220 \\
\hline $\begin{array}{l}\text { Testicular germ cell cancer } \\
\text { case } 14 \text {, pre-therapy }\end{array}$ & 9200 & 9500 & $\begin{array}{l}103.00 \\
\%\end{array}$ & 103 \\
\hline $\begin{array}{l}\text { Testicular germ cell cancer } \\
\text { case } 17 \text {, pre-therapy }\end{array}$ & 13700 & 14300 & $\begin{array}{l}104.00 \\
\%\end{array}$ & 2240 \\
\hline Mean \pm standard deviation & $\begin{array}{l}26,364 \pm 43,52 \\
6\end{array}$ & $\begin{array}{l}26,427 \pm 4 \\
3,729\end{array}$ & $\begin{array}{l}96 \% \\
\pm 12.6 \%\end{array}$ & $\begin{array}{l}2,492 \pm 4 \\
, 227\end{array}$ \\
\hline \multicolumn{5}{|l|}{ Non-trophoblastic cancers } \\
\hline Bladder cancer case 14 & 0.09 & 0.09 & $\begin{array}{l}100.00 \\
\%\end{array}$ & 0.1 \\
\hline Bladder cancer case 77 & 0.09 & 0.1 & $111.00 \%$ & 0.09 \\
\hline Bladder cancer case 120 & 0.12 & 0.12 & $100.0 \%$ & 0.11 \\
\hline Bladder cancer case 121 & 0.15 & 0.15 & $\begin{array}{l}100.00 \\
\%\end{array}$ & 0.15 \\
\hline Bladder cancer case 169 & 1.3 & 1.4 & $\begin{array}{l}108.00 \\
\%\end{array}$ & 1.4 \\
\hline Breast cancer case 1 & 1.3 & 1.3 & $\begin{array}{l}100.00 \\
\%\end{array}$ & 1 \\
\hline Breast cancer case 6 & 0.09 & 0.1 & $111.00 \%$ & 1 \\
\hline Breast cancer case 23 & 0.11 & 0.11 & $\begin{array}{l}100.00 \\
\%\end{array}$ & 0.12 \\
\hline Breast cancer case 32 & 0.66 & 0.62 & $94.00 \%$ & 0.71 \\
\hline Breast cancer case 33 & 0.11 & 0.12 & $\begin{array}{l}109.00 \\
\%\end{array}$ & 0.11 \\
\hline Breast cancer case 37 & 0.14 & 0.14 & $\begin{array}{l}100.00 \\
\%\end{array}$ & 0.15 \\
\hline Breast cancer case 48 & 0.11 & 0.1 & $91.00 \%$ & 0.1 \\
\hline Breast cancer case 40 & 0.09 & 0.09 & $\begin{array}{l}100.00 \\
\%\end{array}$ & 0.1 \\
\hline
\end{tabular}




\begin{tabular}{|c|c|c|c|c|c|}
\hline Breast cancer case 42 & 0.12 & 0.13 & & $\begin{array}{l}108.00 \\
\%\end{array}$ & 0.1 \\
\hline Cervical cancer case 5 & 0.13 & 0.13 & & $\begin{array}{l}100.00 \\
\%\end{array}$ & 0.13 \\
\hline Cervical cancer case 8 & 0.17 & 0.18 & & $\begin{array}{l}106.00 \\
\%\end{array}$ & 0.18 \\
\hline Cervical cancer case 14 & 0.14 & 0.15 & & $\begin{array}{l}107.00 \\
\%\end{array}$ & 0.14 \\
\hline Cervical cancer case 23 & 0.18 & 0.19 & & $\begin{array}{l}106.00 \\
\%\end{array}$ & 0.18 \\
\hline Cervical cancer case 26 & 0.17 & 0.16 & & $94.00 \%$ & 0.17 \\
\hline Cervical cancer case 32 & 0.34 & 0.36 & & $\begin{array}{l}106.00 \\
\%\end{array}$ & 0.35 \\
\hline Cervical cancer case 36 & 0.18 & 0.18 & & $\begin{array}{l}100.00 \\
\%\end{array}$ & 0.2 \\
\hline Cervical cancer case 41 & 0.44 & 0.46 & & $\begin{array}{l}105.00 \\
\%\end{array}$ & 0.4 \\
\hline Cervical cancer case 48 & 0.18 & 0.19 & & $\begin{array}{l}106.00 \\
\%\end{array}$ & 0.18 \\
\hline Cervical cancer case 60 & 0.14 & 0.16 & & $114.00 \%$ & 0.12 \\
\hline Endometrial cancer case 11 & 0.16 & 0.16 & & $\begin{array}{l}100.00 \\
\%\end{array}$ & 0.14 \\
\hline Endometrial cancer case 21 & 0.36 & 0.38 & & $\begin{array}{l}106.00 \\
\%\end{array}$ & 0.32 \\
\hline Endometrial cancer case 53 & 0.09 & 0.09 & & $\begin{array}{l}100.00 \\
\%\end{array}$ & 0.1 \\
\hline Ovarian cancer case 2 & 0.23 & 0.24 & & $\begin{array}{l}104.00 \\
\%\end{array}$ & 0.23 \\
\hline Ovarian cancer case 25 & 0.14 & 0.13 & & $93.00 \%$ & 0.15 \\
\hline Ovarian cancer case 48 & 0.11 & 0.1 & & $91.00 \%$ & 0.1 \\
\hline Ovarian cancer case 82 & 0.1 & 0.11 & & $110.00 \%$ & 0.1 \\
\hline Ovarian cancer case 143 & 0.1 & 0.09 & & $90.00 \%$ & 0.08 \\
\hline Vulvar cancer case 13 & 0.27 & 0.28 & & $\begin{array}{l}104.00 \\
\%\end{array}$ & 0.23 \\
\hline Vulvae cancer case 39 & 0.13 & 0.13 & & $\begin{array}{l}100.00 \\
\%\end{array}$ & 0.12 \\
\hline Mean & $0.24 \pm 0.29$ & $\begin{array}{l}0.25 \\
0.30\end{array}$ & \pm & $\begin{array}{l}102 \% \pm \\
6.2 \%\end{array}$ & $\begin{array}{l}0.26 \\
0.31\end{array}$ \\
\hline $\begin{array}{l}\text { Acetone concentrated pool of } \\
58 \text { cancer samples }\end{array}$ & 0.11 & 0.12 & & $\begin{array}{l}109.00 \\
\%\end{array}$ & 0.1 \\
\hline
\end{tabular}

$\beta$-subunit, this was also $100 \%$ detected by the B152 assay. Similarly, it was found that the FBT11 assay only detected a separated $\beta$-subunit, detecting recombinant hCG dissociated $\beta$ subunit and $\mathrm{C} 5$ dissociated $\beta$-subunit.

As published previously [30], trophoblastic cancers produce cancer hyperglycosylated hCG, and non-trophoblastic cancers produce hyperglycosylated hCG free $\beta$-subunit. Cancer hyperglycosylated hCG and cancer hyperglycosylated hCG free $\beta$-subunit has a $\beta$-subunit with triantennary $\mathrm{N}$-linked oligosaccharides (Figure 1), while pregnancy hyperglycosylated hCG has bi-antennary N-linked oligosaccharides.

The trophoblastic cancers produce a hyperglycosylated hCG was confirmed by Cole LA, and that non-trophoblastic cancers produce a hyperglycosylated hCG free $\beta$-subunit. As shown (Table 1), pre-therapy, 32 trophoblastic cancers just produced hyperglycosylated hCG, B152 hyperglycosylated hCG assay mean detection $96 \% \pm 12.5 \%$ of total hCG.

Non-trophoblastic cancers produced a free $\beta$-subunit (Table 1). 92 non-trophoblastic cancer serum samples were tested. Only 34 of the 92 cancer serum samples was detected by the Siemens Immulite total hCG assay. The balance were assumed to be producing low concentrations of this tumor agent. The B152 hyperglycosylated hCG and $\beta$-subunit assay detected $102 \% \pm 6.2 \%$ of the total hCG immunoreactivity in the remaining 34 serum samples. This indicated that nontrophoblastic cancers produce a hyperglycosylated hCG $\beta$ subunit. It is concluded that all cancers secrete hyperglycosylated hCG or hyperglycosylated hCG $\beta$-subunit. As shown, both hyperglycosylated hCG and hyperglycosylated hCG $\beta$-subunit both act on a TGF- $\beta$-II receptor [16-18]. There was a concern about the 58 of 92 samples missed by this testing as having very low concentrations of hyperglycosylated hCG free $\beta$-subunit. Do those producing low concentrations also produce primarily hyperglycosylated hCG free $\beta$-subunit. The 58 samples were pooled, $3 \mathrm{ml}$ of each, this gave me 174 $\mathrm{ml}$. Using a method described previously [14], the $174 \mathrm{ml}$ was concentrated using $3 \mathrm{X}$ acetone. This precipitated the urine. The precipitate was completely dissolved in $10 \mathrm{ml}$ phosphatebuffered saline buffer and then tested as a $17.4 \mathrm{X}$ concentrate. The concentrate was tested in the Immulite, B152 and FBT11 assays (Table 1). It contained $0.11 \mathrm{ng} / \mathrm{ml}$ according to the Siemens Immulite total hCG assay, $0.12 \mathrm{ng} / \mathrm{ml}$ by the B152 hyperglycosylated hCG assay, and $0.10 \mathrm{ng} / \mathrm{ml}$ using the FBT11 free $\beta$-subunit assay. This confirmed that the low concentration Samples also primarily contained a hyperglycosylated $\mathrm{hCG}$ free $\beta$-subunit.

(Table 1). This is $100 \%$ hormone hCG. As found, B152 assay only detected $0.13 \%$ confirming that this assay only detects hyperglycosylated molecules, and does not detect the hormone hCG. Secondly, the recombinant hCG dissociated $\beta$-subunit was tested. As found, B152 only detected $0.11 \%$ confirming one again that the hormone hCG $\beta$-subunit is also not detected (Table 2).

Then the C5 hyperglycosylated hCG standard was tested, this was $100 \%$ detected by the B152 assay, confirming that this assay is specific for hyperglycosylated molecules. Finally, the assays were tested with C5 hyperglycosylated hCG dissociated

Many of the laboratories demonstrating that non-trophoblastic cancers respond to hyperglycosylated hCG free $\beta$-subunit, or to the molecule secreted by the cancers [31-34], have used hCG $\beta$-subunit, not hyperglycosylated hCG $\beta$-subunit, to promote a cancer response. As published, hyperglycosylated hCG is nicked and dissociated into a $\beta$-subunit to bind the TGF- $\beta$-II receptor [15]. The receptor will respond to hyperglycosylated hCG $\beta$-subunit and to hCG $\beta$-subunit [15]. The LH-hCG hormone receptor, however will not respond to hCG $\beta$-subunit. 
It was concluded that trophoblastic cancers secrete cancer hyperglycosylated hCG dimer. It was also concluded that all non-trophoblastic cancers primarily secrete a hyperglycosylated hCG free $\beta$-subunit. As demonstrated previously, both cancer molecules act on a TGF- $\beta$-II receptor to elicit a growth, anti-apoptosis or invasion response $[16,17,28]$.

\section{Cancer hyperglycosylated hCG and hyperglycosylated hCG free $\beta$-subunit}

Why is hyperglycosylated hCG two molecules, hyperglycosylated hCG and hyperglycosylated hCG free $\beta$ subunit? Trophoblastic cancer produce hyperglycosylated hCG $\alpha-\beta$ subunit dimer, and non-trophoblastic malignancies produce hyperglycosylated hCG free $\beta$-subunit. Both molecules are TGF- $\beta$-II receptor autocrines promoting cancer cell malignancy. The reason needed to deal with both the dimer and the free $\beta$-subunit is very much explained by Beebe et al. [29], and by Ruddon et al. [30]. To complete the synthesis of the $\beta$ subunit requires completion of 6 disulfide bridges. The last two disulfide bridges, $\beta 26-110$ and $\beta 93-100$, requires a specialized disulfide isomerase, only found in trophoblast cells and pituitary cells. Without this isomerase, construction of the $\beta$ subunit is not completed, and $\beta$-subunit does not combine with $\alpha$-subunit. This produces a free $\beta$-subunit as made in non trophoblastic cancers. Only trophoblastic cancers make an $\alpha-\beta$ subunit dimer $[29,30]$.

\section{Hyperglycosylated hCG and hyperglycosylated hCG free $\beta$-subunit the malignancy molecules.}

The malignancy properties of hyperglycosylated hCG and it free $\beta$-subunit were investigated by Cole LA. Multiple cancer cell lines were cultured on top of a Matrigel (Corning, Corning NY) basement membrane and the extent of penetration of the membrane by the cells determined. A wide variety of cancers was investigated (Table 3), ranging from choriocarcinoma cells to testicular germ cell malignancy cells, to cervical endometriod cancer cells, to lung epithelial cancer cells to Hodgkin lymphoma cancer cells. In each cell line control cells with no additive placed in medium (cells produce hyperglycosylated hCG or its free $\beta$-subunit naturally) were compared to cells with $100 \mathrm{ng} / \mathrm{ml}$ additive (Table 3 ).

Table 3. Promotion of cancer cell 24 h growth at $70 \%$ confluency by C5 hyperglycosylated $h C G$ and its $\beta$-subunit.

\begin{tabular}{|c|c|c|c|}
\hline $\begin{array}{l}\text { Cells Ttest vs } 0 \\
\mathrm{ng} / \mathrm{ml}\end{array}$ & $\begin{array}{l}\text { Supplement added to culture } \\
\text { fluid } \% \text { effect on cell count }\end{array}$ & $\begin{array}{l}\% \text { effect on } \\
\text { cell count }\end{array}$ & $\begin{array}{l}P \\
\text { value }\end{array}$ \\
\hline \multirow{2}{*}{$\begin{array}{l}\text { Jar } \\
\text { choriocarcinoma }\end{array}$} & Hyperglycosylated hCG 20 ng/ml & $\begin{array}{l}112 \% \text { cell } \\
\text { count after } 24 \\
\text { h }\end{array}$ & \multirow{2}{*}{$\begin{array}{l}P=0 . \\
0123\end{array}$} \\
\hline & Hyperglycosylated hCG 200 ng/ml & $\begin{array}{l}130 \% \text { cell } \\
\text { count after } 24 \\
\text { h }\end{array}$ & \\
\hline $\begin{array}{l}\text { JEG-3 } \\
\text { choriocarcinoma }\end{array}$ & Hyperglycosylated hCG $20 \mathrm{ng} / \mathrm{ml}$ & $\begin{array}{l}110 \% \text { cell } \\
\text { count after } 24 \\
\text { h }\end{array}$ & $\begin{array}{l}P=0 . \\
0018\end{array}$ \\
\hline
\end{tabular}

\begin{tabular}{|c|c|c|c|}
\hline & & \\
\hline & Hyperglycosylated hCG 200 ng/ml & $\begin{array}{l}128 \% \text { cell } \\
\text { count after } 24 \\
\text { h }\end{array}$ & \\
\hline \multirow{2}{*}{$\begin{array}{l}\text { NTERA Testicular } \\
\text { germ cell }\end{array}$} & Hyperglycosylated hCG 20 ng/ml & $\begin{array}{l}118 \% \text { cell } \\
\text { count after } 24 \\
h\end{array}$ & \multirow{2}{*}{$\begin{array}{l}\mathrm{P}=0 \text {. } \\
0018\end{array}$} \\
\hline & Hyperglycosylated hCG 200 ng/ml & $\begin{array}{l}132 \% \text { cell } \\
\text { count after } 24 \\
\text { h }\end{array}$ & \\
\hline \multirow{2}{*}{$\begin{array}{l}\text { Hec-1-a } \\
\text { endometrial cancer }\end{array}$} & $\begin{array}{l}\text { Hyperglycosylated hCG } \beta \text {-subunit } \\
20 \mathrm{ng} / \mathrm{ml}\end{array}$ & $\begin{array}{l}138 \% \text { cell } \\
\text { count after } 24 \\
\text { h }\end{array}$ & \multirow{2}{*}{$\begin{array}{l}P=0 . \\
0021\end{array}$} \\
\hline & $\begin{array}{l}\text { Hyperglycosylated hCG } \beta \text {-subunit } \\
200 \mathrm{ng} / \mathrm{ml}\end{array}$ & $\begin{array}{l}166 \% \text { cell } \\
\text { count after } \\
24 \mathrm{~h}\end{array}$ & \\
\hline \multirow{2}{*}{$\begin{array}{l}\text { ScaBER } \\
\text { squamous bladder - } \\
\text { cancer }\end{array}$} & $\begin{array}{l}\text { Hyperglycosylated hCG } \beta \text {-subunit } \\
20 \mathrm{ng} / \mathrm{ml}\end{array}$ & $\begin{array}{l}150 \% \text { cell } \\
\text { count after } 24 \\
\text { h }\end{array}$ & \multirow{2}{*}{$\begin{array}{l}P=0 . \\
010\end{array}$} \\
\hline & $\begin{array}{l}\text { Hyperglycosylated hCG } \beta \text {-subunit } \\
200 \mathrm{ng} / \mathrm{ml}\end{array}$ & $\begin{array}{l}156 \% \quad \text { cell } \\
\text { count after } \\
24 \mathrm{~h}\end{array}$ & \\
\hline \multirow{2}{*}{$\begin{array}{l}\text { KLE Endometrial } \\
\text { adenocarcinoma }\end{array}$} & $\begin{array}{l}\text { Hyperglycosylated hCG } \beta \text {-subunit } \\
20 \mathrm{ng} / \mathrm{ml}\end{array}$ & $\begin{array}{l}117 \% \text { cell } \\
\text { count after } 24 \\
\text { h }\end{array}$ & \multirow{2}{*}{$\begin{array}{l}P=0 . \\
0.001\end{array}$} \\
\hline & $\begin{array}{l}\text { Hyperglycosylated hCG } \beta \text {-subunit } \\
200 \mathrm{ng} / \mathrm{ml}\end{array}$ & $\begin{array}{l}132 \% \text { cell } \\
\text { count after } 24 \\
\text { h }\end{array}$ & \\
\hline \multirow{2}{*}{$\begin{array}{l}\text { SK-MES-1 } \\
\text { Epithelial } \\
\text { cancer }\end{array}$} & $\begin{array}{l}\text { Hyperglycosylated hCG } \beta \text {-subunit } \\
20 \mathrm{ng} / \mathrm{ml}\end{array}$ & $\begin{array}{l}134 \% \text { cell } \\
\text { count after } 24 \\
\text { h }\end{array}$ & \multirow{2}{*}{$\begin{array}{l}\mathrm{P}=0 . \\
005\end{array}$} \\
\hline & $\begin{array}{l}\text { Hyperglycosylated hCG } \beta \text {-subunit } \\
200 \mathrm{ng} / \mathrm{ml}\end{array}$ & $\begin{array}{l}163 \% \text { cell } \\
\text { count after } 24 \\
\text { h }\end{array}$ & \\
\hline \multirow{2}{*}{ KM-H2 } & $\begin{array}{l}\text { Hyperglycosylated hCG } \beta \text {-subunit } \\
20 \mathrm{ng} / \mathrm{ml}\end{array}$ & $\begin{array}{l}120 \% \text { cell } \\
\text { count after } 24 \\
\text { h }\end{array}$ & \multirow{2}{*}{$\begin{array}{l}P=00 \\
11\end{array}$} \\
\hline & $\begin{array}{l}\text { Hyperglycosylated hCG } \beta \text {-subunit } \\
200 \mathrm{ng} / \mathrm{ml}\end{array}$ & $\begin{array}{l}145 \% \text { cell } \\
\text { count after } 24 \\
\text { h }\end{array}$ & \\
\hline \multirow{2}{*}{$\begin{array}{l}\text { T24 Bladder } \\
\text { epithelial } \\
\text { carcinoma }\end{array}$} & $\begin{array}{l}\text { Hyperglycosylated hCG } \beta \text {-subunit } \\
20 \mathrm{ng} / \mathrm{ml}\end{array}$ & $\begin{array}{l}110 \% \text { cell } \\
\text { count after } 24 \\
\text { h }\end{array}$ & \multirow{2}{*}{$\begin{array}{l}P=0 . \\
123\end{array}$} \\
\hline & $\begin{array}{l}\text { Hyperglycosylated hCG } \beta \text {-subunit } \\
200 \mathrm{ng} / \mathrm{ml}\end{array}$ & $\begin{array}{l}128 \% \text { cell } \\
\text { count after } 24 \\
h\end{array}$ & \\
\hline \multirow{2}{*}{$\begin{array}{l}\text { Caski epithelial } \\
\text { cervical carcinoma }\end{array}$} & $\begin{array}{l}\text { Hyperglycosylated hCG } \beta \text {-subunit } \\
20 \mathrm{ng} / \mathrm{ml}\end{array}$ & $\begin{array}{l}115 \% \text { cell } \\
\text { count after } 24 \\
\text { h }\end{array}$ & \multirow{2}{*}{$\begin{array}{l}\mathrm{P}=0 . \\
008\end{array}$} \\
\hline & $\begin{array}{l}\text { Hyperglycosylated hCG } \beta \text {-subunit } \\
200 \mathrm{ng} / \mathrm{m}\end{array}$ & $\begin{array}{l}142 \% \text { cell } \\
\text { count after } 24 \\
\text { h }\end{array}$ & \\
\hline
\end{tabular}

Control cells penetrated the basement membrane, $36 \pm 12 \%$ to $49 \pm 15 \%$. Additive cells penetrated the basement membrane to a much more significant extent $69 \pm 6.5 \%$ to $88 \pm 6.0 \%$. Each cell line showed a significant difference between control cultures and additive cultures.

Multiple studies show that molecules acting on TGF- $\beta$-II receptors promote enzymatic cell to cell invasion by promoting production of metalloproteinases and collagenases [31-35]. It is concluded that hyperglycosylated hCG and it free $\beta$-subunit 
drive cancer cell metalloproteinases and collagenases production.

The action of hyperglycosylated hCG and its free $\beta$-subunit on cancer grow the was investigated. Ten different cultured cancer cell lines were cultured to $70 \%$ confluency, and then cultured with $20 \mathrm{ng} / \mathrm{ml}$ hyperglycosylated hCG and hyperglycosylated hCG free $\beta$-subunit, and then with $200 \mathrm{mg} / \mathrm{ml}$ hyperglycosylated hCG and hyperglycosylated hCG free $\beta$ subunit supplement. Cell growth was compared to no supplement control cultures (Table 3 ). A wide variety of cells was investigated, ranging from Jar and JEG-3 choriocarcinoma cells, NTERA testicular germ cell cancer cells, Hec-1-a and KLE endometrial cancer cells, ScaBER and T24 bladder cancer cells, SK-MES-1 lung cancer, Caski cervical cancer and $\mathrm{KM}-\mathrm{H} 2$ lymphoma cells. The addition of $20 \mathrm{ng} / \mathrm{ml}$ hyperglycosylated hCG and hyperglycosylated hCG free $\beta$ subunit caused $110 \%$ to $134 \%$ enhancement in cell population, the addition of $200 \mathrm{ng} / \mathrm{ml}$ hyperglycosylated hCG and hyperglycosylated hCG free $\beta$-subunit caused a significantly greater (all additives caused a significant advancement in cell growth) enhancement in cell population, $128 \%$ to $163 \%$ of the control population.

Clearly, hyperglycosylated hCG and its free $\beta$-subunit enhance cell growth and promote cell to cell invasion through the actions of metalloproteinases and collagenases. Most of these studies have been repeated and confirmed by the 8 independent other groups who have very much confirmed our studies using a wide range of alternative cell lines [35-38]. Multiple other authors have also shown that hyperglycosylated hCG and it free $\beta$-subunit also blocks apoptosis, another action in malignancy [39]. All told, hyperglycosylated hCG and hyperglycosylated hCG free $\beta$-subunit promote the production of the invasive enzymes collagenases and metalloproteinases, promote cell growth, and block cellular apoptosis, or have all malignancy properties.

Having shown that hyperglycosylated hCG and hyperglycosylated hCG $\beta$-subunit promote all malignancy properties, it was necessary to show the occurrence of these tumor agents.

\section{Tumor markers}

The occurrence of hyperglycosylated hCG and its free $\beta$ subunit as cancer markers were investigated (Table 4). The serum hyperglycosylated hCG and its free $\beta$-subunit were measured using the B152 immunoassay, and the urine degradation products of hyperglycosylated hCG and hyperglycosylated hCG $\beta$-subunit, the terminal degradation product $\beta$-core fragment using the B204 immunoassay. The B204 immunoassay detects $\beta$-core fragment and nicked hyperglycosylated hCG $\beta$-subunit. The serum and urine on 110 trophoblastic cancer cases were examined, and serum on 849 non-trophoblastic cancer cases, and urine on 2,167 nontrophoblastic cancer cases (Table 4).

Table 4. Serum hyperglycosylated $h C G+\beta$-subunit (B152 assay) and urine degradation product hyperglycosylated $h C G \quad \beta$-subunit $+\beta$-core fragment (B204 assay) as tumor markers.

\begin{tabular}{|c|c|c|c|c|c|c|}
\hline \multirow[t]{2}{*}{ Source } & \multicolumn{3}{|c|}{ Serum, B152 assay } & \multirow{2}{*}{$\begin{array}{l}\text { Urine } \\
\text { assay }\end{array}$} & \multicolumn{2}{|l|}{ B204 } \\
\hline & $\begin{array}{l}\text { \#Cas } \\
\text { es }\end{array}$ & $\begin{array}{l}\text { \#Detec } \\
\text { ted }\end{array}$ & $\begin{array}{l}\text { Sensitiv } \\
\text { ity }\end{array}$ & & $\begin{array}{l}\text { \#Positi } \\
\text { ve }\end{array}$ & $\begin{array}{l}\text { Sensitiv } \\
\text { ity }\end{array}$ \\
\hline
\end{tabular}

Trophoblastic

malignancies

\begin{tabular}{lcccccc}
\hline Choriocarcinoma & 63 & 63 & $\begin{array}{l}100.00 \\
\%\end{array}$ & 63 & 63 & $\begin{array}{l}100.00 \\
\%\end{array}$ \\
\hline Ovarian germ cell cancer & 30 & 30 & $\begin{array}{l}100.00 \\
\%\end{array}$ & 11 & 11 & $\begin{array}{l}100.00 \\
\%\end{array}$ \\
\hline Testicular germ cell cancer & 17 & 17 & $\begin{array}{l}100.00 \\
\%\end{array}$ & 17 & 17 & $\begin{array}{l}100.00 \\
\%\end{array}$ \\
\hline Total & 110 & 110 & $100.0 \%$ & 110 & 110 & $100.0 \%$ \\
\hline
\end{tabular}

Non-trophoblastic

malignancy

\begin{tabular}{|c|c|c|c|c|c|c|}
\hline Bladder cancer & 170 & 60 & $35.00 \%$ & 140 & 62 & $44.00 \%$ \\
\hline Breast cancer & 42 & 15 & $36.00 \%$ & 456 & 156 & $34.00 \%$ \\
\hline Cervical cancer & 60 & & $37.00 \%$ & 410 & 197 & $48.00 \%$ \\
\hline Colorectal cancer & 136 & 23 & $17.00 \%$ & 80 & 29 & $36.00 \%$ \\
\hline Endometrial cancer & 55 & 18 & $33.00 \%$ & 233 & 103 & $44.00 \%$ \\
\hline Gastric cancer & & & & 205 & 90 & $44.00 \%$ \\
\hline Hepatic cancer & & & & 46 & 21 & $44.00 \%$ \\
\hline Lung cancer & 143 & 26 & $18.00 \%$ & 154 & 38 & $25.00 \%$ \\
\hline Intestinal cancer & & & & 17 & 8 & $47.00 \%$ \\
\hline Lymphoma & & & & 41 & 13 & $32.00 \%$ \\
\hline Ovarian cancer & 150 & 57 & $38.00 \%$ & 207 & 145 & $70.00 \%$ \\
\hline Pancreatic cancer & 29 & 10 & $33.00 \%$ & 29 & 16 & $55.00 \%$ \\
\hline Prostate cancer & & & & 12 & 9 & $75.00 \%$ \\
\hline Renal cancer & & & & 66 & 32 & $48.00 \%$ \\
\hline Uterine cancer & & & & 63 & 26 & $41.00 \%$ \\
\hline Vulvar cancer & 64 & 26 & $41.00 \%$ & 8 & 4 & $50.00 \%$ \\
\hline Total & 849 & 257 & $30.00 \%$ & 2167 & 949 & $44.00 \%$ \\
\hline \multicolumn{7}{|l|}{ Healthy } \\
\hline $\begin{array}{l}\text { NED, post cancer } \\
\text { chemotherapy }\end{array}$ & 33 & & & 33 & 2 & $6.00 \%$ \\
\hline NED, post cancer surgery & 21 & & & 21 & 1 & $5.00 \%$ \\
\hline $\begin{array}{l}\text { Healthy female, no cancer } \\
\text { history }\end{array}$ & 72 & & & 72 & 2 & $3.00 \%$ \\
\hline $\begin{array}{l}\text { Healthy male, no cancer } \\
\text { history }\end{array}$ & 28 & & & 28 & 1 & $4.00 \%$ \\
\hline Total & 154 & & & 154 & 6 & $4.00 \%$ \\
\hline
\end{tabular}

Benign Disease

\begin{tabular}{lccc}
\hline $\begin{array}{l}\text { Benign gynecological } \\
\text { lesion, tumor }\end{array}$ & 28 & 0 & $0.00 \%$ \\
\hline Benign lung lesion & 4 & 0 & $0.00 \%$ \\
\hline $\begin{array}{l}\text { Follicular ovarian cyst, } \\
\text { benign }\end{array}$ & 67 & 0 & $0.00 \%$ \\
\hline
\end{tabular}


Citation: Cole LA. Hyperglycosylated hCG drives malignancy in cancer cases. J Mol Oncol Res. 2017;1(1):1-21.

\begin{tabular}{lccc}
\hline Benign endometrial wart & 53 & 0 & $0.00 \%$ \\
\hline $\begin{array}{l}\text { Benign ovarian cyst, non- } \\
\text { functional }\end{array}$ & 26 & 0 & $0.00 \%$ \\
\hline $\begin{array}{l}\text { Benign prostate } \\
\text { hyperplasia }\end{array}$ & 8 & 0 & $0.00 \%$ \\
\hline Cervical carcinoma in-situ & 12 & 0 & $0.00 \%$ \\
\hline Cervical dyskaryosis & 66 & 0 & $0.00 \%$ \\
\hline Condyloma & 30 & 0 & $0.00 \%$ \\
\hline Endometriosis & 16 & 0 & $0.00 \%$ \\
\hline Myoma & 27 & 0 & $0.00 \%$ \\
\hline Total & 337 & 0 & $0.00 \%$ \\
\hline
\end{tabular}

\begin{tabular}{|c|c|c|c|}
\hline Ovarian Endometrioid carcinoma & IV & Persistent & 0.12 \\
\hline Ovarian Endometrioid carcinoma & IV & $\begin{array}{l}\text { New, not } \\
\text { treated }\end{array}$ & 0.15 \\
\hline Ovarian Serous cystadenocarcinoma & IIIc & $\begin{array}{l}\text { New, not } \\
\text { treated }\end{array}$ & 0.2 \\
\hline Ovarian Serous cystadenocarcinoma & IIIc & Persistent & 0.2 \\
\hline Ovarian Serous cystadenocarcinoma & IIIc & Recurrent & 0.25 \\
\hline Ovarian Serous cystadenocarcinoma & IV & Recurrent & 0.4 \\
\hline Ovarian Serous cystadenocarcinoma & IV & Recurrent & 0.4 \\
\hline Ovarian Brenner tumor & la & $\begin{array}{l}\text { New, not } \\
\text { treated }\end{array}$ & 0.58 \\
\hline Ovarian Serous cystadenocarcinoma & IIIc & $\begin{array}{l}\text { New, not } \\
\text { treated }\end{array}$ & 0.6 \\
\hline Ovarian Serous cystadenocarcinoma & IIIc & New & 0.75 \\
\hline Ovarian Brenner tumor & la & $\begin{array}{l}\text { New, not } \\
\text { treated }\end{array}$ & 0.88 \\
\hline $\begin{array}{l}\text { Ovarian } \\
\text { cystadenocarcinomacucystcancerccancercysta } \\
\text { denocarcinoma }\end{array}$ & IIIc & Recurrent & 1.2 \\
\hline Serous cystadenocarcinoma & $\|$ & Recurrent & 1.6 \\
\hline Ovarian Serous cystadenocarcinoma & IIIc & Recurrent & 2.1 \\
\hline Ovarian Endometrioid carcinoma & III & Recurrent & 2,3 \\
\hline Ovarian Serous cystadenocarcinoma & IIIc & Persistent & 2.5 \\
\hline $\begin{array}{l}\text { Ovarian } \\
\text { ccarcinomacarcinomacystadenocarcinoma }\end{array}$ & la & $\begin{array}{l}\text { New, not } \\
\text { treated }\end{array}$ & 2.9 \\
\hline Ovarian Endometrioid carcinoma & 1 & $\begin{array}{l}\text { New, not } \\
\text { treated }\end{array}$ & 3.1 \\
\hline Ovarian Granulosa-theca cell malignancy & IIIc & Recurrent & 3.1 \\
\hline Ovarian Serous cystadenocarcinoma & $\|$ & $\begin{array}{l}\text { New, not } \\
\text { treated }\end{array}$ & 3.5 \\
\hline Ovarian Granulosa-theca cell malignancy & IIIc & Persisent & 3.7 \\
\hline Ovarian Mucinous cystadenocarcinoma & III & Recurrent & 4.2 \\
\hline Ovarian Serous cystadenocarcinoma & III & New & 4.5 \\
\hline Ovarian Serous cystadenocarcinoma & III & $\begin{array}{l}\text { New, not } \\
\text { treated }\end{array}$ & 4.3 \\
\hline Ovarian Clear cell carcinoma & IIIc & $\begin{array}{l}\text { New, not } \\
\text { treated }\end{array}$ & 4.8 \\
\hline Ovarian Clear cell carcinoma & IIIc & Recurrent & 5.5 \\
\hline Ovarian Serous cystadenocarcinoma & IIIc & New & 6.3 \\
\hline Ovarian Serous cystadenocarcinoma & IIIc & $\begin{array}{l}\text { New, not } \\
\text { treated }\end{array}$ & 6.6 \\
\hline Ovarian Mixed epithelial tumor & IIIc & $\begin{array}{l}\text { New, not } \\
\text { treated }\end{array}$ & 7.1 \\
\hline Ovarian Mixed epithelial tumor & III & New & 7.9 \\
\hline Ovarian Serous cystadenocarcinoma & IIIc & $\begin{array}{l}\text { New, not } \\
\text { treated }\end{array}$ & 8.1 \\
\hline Ovarian Serous cystadenocarcinoma & IIIc & Persistent & 8.8 \\
\hline Ovarian Serous cystadenocarcinoma & IIIc & $\begin{array}{l}\text { New, not } \\
\text { treated }\end{array}$ & 9 \\
\hline
\end{tabular}

As found, $100 \%$ of trophoblastic cancer case were detected in serum and urine (Table 4). In contrast, an average of $30 \%$ of non-trophoblastic cancer cases were detected in serum, and $44 \%$ of cases in urine samples. The higher detection in urine may be due to the rapid blood clearance of hyperglycosylated hCG free $\beta$-subunit and its degradation products.

Detection of non-trophoblastic cancers varied greatly according to cancer site. In serum, detection ranged from $17 \%$ with colorectal cancers to $38 \%$ with ovarian cancers. In urine, using the B204 assay, detection ranged from 34\% with breast cancers to $70 \%$ with ovarian malignancies (Table 4). Questions have been raised on why $34 \%$ to $70 \%$ and not $100 \%$, since $100 \%$ of cancers show malignancy?

\section{Simple and complex autocrines}

There are two kinds of TGF- $\beta$ autocrines, "simple autocrines" and "complex autocrines" [40-43]. Simple autocrines are produced at low concentration, are secreted and act directly on the cancer cell TGF- $\beta$-II receptor without necessarily circulating [44] Complex autocrines are produced at higher concentration. They are secreted, and circulate in the blood stream before acting back on the original cancer cell TGF- $\beta$-II receptor. Are the cancers simple autocrine or complex autocrine TGF- $\beta$-II receptor cases? Does simple autocrine production explain the lower detection, $34 \%-70 \%$ in nontrophoblastic cancers (Table 4)?

To address this issue 56 new non-treated ovarian cancer cases were tested providing urine samples with the B204 assay. The current assay used has a sensitivity of $1.4 \mathrm{fmol} / \mathrm{ml}$, and the cut off in the tumor marker assay of $3.0 \mathrm{fmol} / \mathrm{ml}$. A significantly more sensitive assay was developed by 10 -fold reducing the plating concentration of B204 antibody, and by extending the first incubation time from $2 \mathrm{~h}$ to $6 \mathrm{~h}$. The new super-sensitive assay detected down to $0.08 \mathrm{fmol} / \mathrm{ml}$, and has a tumor marker cut-off of $0.10 \mathrm{fmol} / \mathrm{ml}$. This assay was used to test the 56 ovarian cancer urines Table 5.

Table 5. Ovarian cancer super-sensitive urine B204 assay. Tumor marker study of 56 ovarian cancer cases receiving no therapy using super-sensitive B204 assay (sensitivity $>0.1 \mathrm{fmol} / \mathrm{ml}$ )

\begin{tabular}{|c|c|c|}
\hline Pathologic Diagnosis & Stag & $\begin{array}{l}\beta \text {-core } \\
\text { fraqment }\end{array}$ \\
\hline
\end{tabular}




\begin{tabular}{|c|c|c|c|}
\hline Ovarian Serous cystadenocarcinoma & III & Persistent & 9.5 \\
\hline Ovarian Mixed epithelial tumor & Ilc & $\begin{array}{l}\text { New, not } \\
\text { treated }\end{array}$ & 10 \\
\hline Ovarian Mixed epithelial tumour & $\mathrm{Ilb}$ & $\begin{array}{l}\text { New, not } \\
\text { treated }\end{array}$ & 11.3 \\
\hline Ovarian Serous cystadenocarcinoma & III & New & 11.4 \\
\hline Ovarian Serous cystadenocarcinoma & IV & Recurrent & 11.4 \\
\hline Ovarian Serous cystadenocarcinoma & IV & Recurrent & 12 \\
\hline Ovarian Serous cystadenocarcinoma & IIIc & Recurrent & 12 \\
\hline Ovarian Serous cystadenocarcinoma & IIlc & Recurrent & 12 \\
\hline Ovarian Endometrioid carcinoma & Ilc & $\begin{array}{l}\text { New, not } \\
\text { treated }\end{array}$ & 12.2 \\
\hline Ovarian Endometrioid carcinoma & III & Persistent & 13.1 \\
\hline Ovarian Mixed mesodermal carcinoma & III & Recurrent & 14.4 \\
\hline Ovarian Mixed mesodermal carcinoma & III & Recurrent & 16.3 \\
\hline Ovarian Serous cystadenocarcinoma & IV & Recurrent & 16.9 \\
\hline Ovarian Serous cystadenocarcinoma & IV & Recurrent & 17.5 \\
\hline Ovarian Serous cystadenocarcinoma & IIIc & $\begin{array}{l}\text { New, not } \\
\text { treated }\end{array}$ & 18.8 \\
\hline Ovarian Serous cystadenocarcinoma & IIIC & Persistent & 20 \\
\hline Ovarian Mixed epithelial tumor & IIlc & Recurrent & 20 \\
\hline Ovarian Mixed epithelial tumor & III & Recurrent & 21 \\
\hline Ovarian Serous cystadenocarcinoma & IV & $\begin{array}{l}\text { New, not } \\
\text { treated }\end{array}$ & 28 \\
\hline Ovarian Serous cystadenocarcinoma & IV & $\begin{array}{l}\text { New, not } \\
\text { treated }\end{array}$ & 29 \\
\hline Ovarian Serous cystadenocarcinoma & III & New & 32 \\
\hline Ovarian Serous cystadenocarcinoma & $\mathrm{llb}$ & $\begin{array}{l}\text { New, not } \\
\text { treated }\end{array}$ & 41 \\
\hline Ovarian Malignant dermoid cyst/teratoma & $\mathrm{llb}$ & New & 54 \\
\hline
\end{tabular}

As shown in Table 5, 56 of 56 cancer urines were positive using the super-sensitive B204 assay. Thirty-nine (70\%) of the urines would be detected by a tumor marker assay with 3.0 $\mathrm{fmol} / \mathrm{ml}$ cut-off, and 56 of 56 urine $(100 \%)$ would be detected in the assay using the new $0.1 \mathrm{fmol} / \mathrm{ml}$ cut-off.

It was concluded that thirty-nine cases probably produced a complex autocrine ( $>3.0 \mathrm{fmol} / \mathrm{ml}$ cut-off samples), and the balance, seventeen cases, probably produced tiny concentrations $(<3.0 \mathrm{fmol} / \mathrm{ml})$, or were simple autocrines. It was clear that $100 \%$ of cases produced hyperglycosylated hCG and its free $\beta$-subunit. Seemingly $100 \%$ of all cancers, as simple autocrine and complex autocrine TGF- $\beta$-II cancers.

In support of the concept that all cancers produced simple and complex autocrines, Acevedo et al. [45-47] used flow cytometry to sensitively examine membrane-associated hCGrelated molecules produced by cancer cells. Each showed and confirmed, as indicated in Table 5 that $100 \%$ of cancer cells produced the tumor markers. It was concluded that in reality
$100 \%$ of all cancer produce hyperglycosylated hCG and its free $\beta$-subunit.

\section{Benign diseases}

If hyperglycosylated hCG and its free $\beta$-subunit control cancer cell malignancy, then these molecules should not be expressed in benign diseases. 284 urines from women with a wide variety of benign diseases were tested, using the B204 $3.0 \mathrm{fmol} / \mathrm{ml}$ cutoff assay (Table 4). None of the 284 benign disease urines contained B204 reactive materials.

\section{Conclusions}

It was concluded that $100 \%$ of cancers produce hyperglycosylated $\mathrm{hCG}$ or its free $\beta$-subunit, and that no benign disease cases are positive for this malignancy promoter. It was also concluded that expression of the hCG $\beta$-subunit gene by cells marked cancer, and synthesis of hyperglycosylated $\mathrm{hCG}$ or hyperglycosylated $\mathrm{hCG}$ free $\beta$ subunit made a cell malignant, or a cancer cell.

\section{References}

1. Miller DM, Blume S, Borst M, et al. Oncogenes, malignant transformation, and modern medicine. Am J Med Sci. 1990;300:59-9.

2. Croce CM. Oncogenes and cancer. N Engl J Med. 2008;358:502-11.

3. Yokota J. Tumor progression and metastasis. Carcinogenesis. 2000;21:497-503.

4. Martin S. The Hunting of the Src, G. Nature Rev Molec Cell Biol. 2001;2:467.

5. Todd R, Wong DT. Oncogenes. Anticancer Res. 1999;19:4729-46.

6. Summy JMM, Gallick GE. Src family kinases in tumor progression and metastasis. Cancer and Metast Rev. 2003;22:337-58.

7. Bos JL. ras oncogenes in human cancer: a review. Cancer Research. 1989;49:4682-89.

8. Reiss M. TGF-beta and cancer. Microbes Infect. 1999;1:1327-47.

9. Bierie B. TGF- $\beta$ and cancer. Cytokine Growth Factor Rev. 2006;17:29-40.

10. deCaestecker MP, Piek E, Roberts AB, et al. J Natl Cancer Inst. 2000;92:1388-02.

11. Akhurst RJ, Balmain A. Genetic events and the role of TGF beta in epithelial tumour progression. J Pathol. 1999;187:82-90.

12. Murphy G, Reynolds JJ, Whitham SE, et al. Transforming growth factor beta modulates the expression of collagenase and metalloproteinase inhibitor. Euro MoleSc Biol Org J. 1987;6:1899-1904.

13. Akhurst RJ. TGF- $\beta$ antagonists: Why suppress a tumor suppressor? J Clin Invest. 2002; 109:1533-36.

14. Elliott MM, Kardana A, Lustbader JW, et al. Carbohydrate and Peptide structure of the $\alpha$ - and $\beta$-subunits of human chorionic gonadotropin from normal and aberrant 
pregnancy and choriocarcinoma. EndocrinE. 1997; 7:15-32.

15. Cole LA. The difference between the hormone hCG and the autocrine hyperglycosylated hCG. Biosci Reports. 2017.

16. Butler SA, Ikram MS, Mathieu S, et al. The increase in bladder carcinoma cell population induced by the free beta subunit of hCG is a result of an anti-apoptosis effect and not cell proliferation. Brit J Cancer. 2000;82:1553-56.

17. Berndt S, Blacher S, Munuat C, et al, Hyperglycosylated human chorionic gonadotropin stimulates angiogenesis through TGF- $\beta$ receptor activation. FASEB J. 2013;12:1309-21.

18. Ahmud F, Ghosh S, Sinha S, et al. TGF- $\beta$-induced hCG- $\beta$ regulates redox homeostasis in glioma cells. Molec Cellul Biochem. 2015;399:105-12.

19. Cole LA, Dai D, Leslie KK, et al. Gestational trophoblastic diseases 1 Pathophysiology of hyperglycosylated hCG-regulated neoplasia. Gynecologic Oncology. 2006;102:144-49.

20. Sasaki Y, Ladner DG, Cole LA. Hyperglycosylated hCG the source of pregnancy failures. Fertil Steril. 2008;89:1871-1786.

21. Evans J, Salamonsen LA, Menkhorst E, et al. Dynamic changes in hyperglycosylated human chorionic gonadotrophin throughout the first trimester of pregnancy and its role in early placentation. Hum Reprod. 2015;30:1029-38.

22. Cole LA, Brennan MC, Hsu C-D, et al. Hyperglycosylated hCG, A Sensitive Screening Test For Preeclampsia / Gestational Hypertension. Preg Hypertension. 2017.

23. Bahado-Singh RO, Oz AU, Kingston JM, et al. The role of hyperglycosylated hCG in trophoblast invasion and the prediction of subsequent pre-eclampsia. Prenat Diagn. 2002;22:478-81.

24. Cole LA. Ovarian hyperglycosylated hCG and pituitary sulfated hCG both climax with the menstrual mid-cycle LH peak. Matern Child Health J. 2017.

25. Iles RK. Ectopic hCG $\beta$ expression by epithelial cancer: Malignant behavior metastasis and inhibition of tumor cell apoptosis. Molec Cellul Endocrinol. 2007;260-70.

26. Jankowska A, Gunderson SI, Warchol JB, et al. Reduction of hCG $\beta$ subunit expression by modified U1 snRNA caused apoptosis in cervical cancer cells. Molec Cancer. 2008; 7: 26-9.

27. Li D, Wen X, Ghali L, et al. hCG $\beta$ expression by cervical squamous carcinoma-in vivo histological association with tumour invasion and apoptosis. Histopathol. 2008;53:147-55.

28. Cole LA, Butler SA. Hyperglycosylated hCG, hCG $\beta$ and Hyperglycosylated hCG $\beta$ Interchangeable Cancer Promoters. Molec Cellul Endcrinol. 2012;349:232-38.

29. Cole LA. hCG and Hyperglycosylated hCG Carbohydrate Structures Corrected. J Glycobiol. 2014;3:1000114.

30. Beebe JS, Huth JR, Ruddon RW. Combination of the chorionic gonadotropin free beta-subunit with alpha. Endocrinol. 1990;126:384-91.
31. Ruddon RW, Sherman SA, Bedows E. Protein folding in the endoplasmic reticulum: Lessons learned from the human chorionic gonadotropin $\beta$-subunit. Protein Science 1996;5:1443-52.

32. Murphy G, Reynolds JJ, Whitham SE, et al. Transforming growth factor beta modulates the expression of collagenase and metalloproteinase inhibitor. Euro Molec Biol Org J. 1987;6:1899-1904.

33. Uría JA, Jiménez MG, Balbín M, et al. Differential Effects of Transforming Growth Factor- $\beta$ on the Expression of Collagenase-1 and Collagenase-3 in Human Fibroblasts. J Biol Chem. 1998;273:9769-77.

34. Yamane K, Ihn H, Asano Y, et al. Antagonistic effects of TNF-alpha on TGF-beta signaling through downregulation of TGF-beta receptor type II in human dermal fibroblasts. J Immunol. 2003;171:3855-62.

35. Qureshi Y, Sylvester J, Mabrouk E, et al. TGF-?-induced expression of tissue inhibitor of metalloproteinases-3 gene in chondrocytes is mediated by extracellular signalregulated kinase pathway and $\mathrm{Sp} 1$ transcription factor. $\mathrm{J}$ Cellular Physiol. 2005;203:345-52.

36. Jankowska A, Gunderson SI, Warchol, JB. Reduction of hCG $\beta$ subunit expression by modified U1 snRNA caused apoptosis in cervical cancer cells. Molec Cancer. 2008;7:26-9.

37. Gillott DJ, Iles RK, Chard T. The effects of beta-human chorionic gonadotrophin on the in vitro growth of bladder cancer cell lines. Br J Cancer. 1996;73:323-26.

38. Guo X, Liu G, Schauer IG, et al. Overexpression of the $\beta$ Subunit of Human Chorionic Gonadotropin Promotes the Transformation of Human Ovarian Epithelial Cells and Ovarian Tumorigenesis. Am J Pathol. 2011;179:1385-93.

39. Hamade AL, Nakabayashi K, Sato A, et al. Transfection of antisense chorionic gonadotropin $\beta$ gene into choriocarcinoma cells suppresses the cell proliferation and induces apoptosis. J Clin Endocrinol Metab. 2005;90:4873-79.

40. Isklander YL, Byrant JL, Zemn RA, et al. Tumorigenesis and metastasis of neoplastic Karposis's Sarcoma cell line in immunodeficient mice blocked by a human pregnancy hormone. Nature. 1995;375:64-8.

41. Cole LA, Butler SA. B152 anti-hyperglycosylated human chorionic gonadotropin free $\beta$-Subunit. A new, possible treatment for cancer. J Reprod Med. 2015;60:13-20.

42. Offermann MK, Faller DV. Autocrine induction of major histocompatibility complex class I antigen expression results from induction of beta interferon in oncogene transformed BALB/c-3T3 cells. Mol Cell Biol. 1989;9:1969-77.

43. Ikushima $\mathrm{H}$, Miyazono $\mathrm{K}$. TGF $\beta$ signalling: a complex web in cancer progression. Nature Reviews Cancer. 2010;10:415-24.

44. Gold LI, Saxena B, Mittal KR, et al. Increased Expression of Transforming Growth Factor $\beta$ Isoforms and Basic Fibroblast Growth Factor in Complex Hyperplasia and Adenocarcinoma of the Endometrium: Evidence for 
Paracrine and Autocrine Action. Cancer Res. 1994;54:2347-58.

45. Zeinoun Z, Teugels E, Vermeij J, et al. Restoration of an impaired TGF-beta1 autocrine growth-inhibitory circuit results in growth inhibition of ovarian epithelial cancer cells and complete inhibition of their tumorigenicity. Cancer Epidemiol. 2003;27:380-8.

46. Munir S, Xu G, Wu Y, Yang B et al. Nodal and ALK7 inhibit proliferation and induce apoptosis in human trophoblast cells. J Biol Chem. 2004;279:31277-86.

47. Acevedo HF, Krichevsky A, Campbell-Acevedo EA, et al. Flow cytometry method for the analysis of membrane- associated human chorionic gonadotropin, its subunits, and fragments on human cancer cells. Cancer. 1992;69:1818-28.

\section{*Correspondence to}

Laurence A. Cole

USA hCG Reference Service, 34 Broadmoor Way, P.O. Box 950Angel Fire, New Mexico

Tel: 575-377-1330

E-mail: larry@hcglab.com 